\title{
PENGARUH BIAYA PRODUKSI TERHADAP PENDAPATAN PETANI MANDIRI KELAPA SAWIT DI KECAMATAN SEGAH
}

\author{
Abdul Hakim \\ Sekolah Tinggi Ilmu Ekonomi Muhammadiyah \\ Tanjung Redeb - Kabupaten Berau
}

\begin{abstract}
The purpose of this study was to analyze the income of independent oil palm farmers in the Segahdistrict. The analytical tool used are multiple linear regression equations, correlation coefficients, $t$ test and calculated fest Based on the results of the analysis, it was found that the multiple linear regression equation influences the cost of seedlings, fertilizer costs and financing the eradication of weeds against the income of independent oil palm farmers in Segah district is $Y=-1,469+0,639 X 1+4,150 \times 3$. To measure the degree of the correlation between seed costs, fertilizer costs and financing of weed eradication of the income of independent oil palm farmers in Segah district, the researcher used a multiple correlation coefficient $(R)=0.993$ which means that the variable costs of seeds, fertilizer costs and weed eradication costs affect the income of farmers independent of oil palm in Segah District, the coefficient of determination $R=0.987$ which showed that the income of independent farmers of oil palm in Segah district is influenced by seed costs, fertilizer costs, and weed eradication costs while the remaining $1.13 \%(1-0.987)$ is a factor which is not examined

Based on testing using $f$ test where $f$ arithmetic is $0.040<0.10$ and $t$ count value is $2.617>1.943$, it can be concluded that the proposed hypothesis is accepted
\end{abstract}

Keyword : cost of seedlings, fertilizer costs and financing the eradication of weeds

\section{PENDAHULUAN \\ LATAR BELAKANG}

Kelapa sawit adalah tanaman perkebunan penting di dunia yang dapat menghasilkan berbagai produk industri makanan, kimia, kosmetik, bahan dasar industri berat dan ringan, biodiesel, dan lainlain. Tanaman sawit yang diduga berasal dari Afrika didatangkan ke Indonesia oleh pemerintah Hindia Belanda pada tahun 1848. Beberapa bijinya ditanam di Kebun Raya Bogor, sementara sisa benihnya ditanam di tepi-tepi jalan sebagai tanaman hias di Deli Sumatera Utara pada tahun 1870-an. Berkembangnya perkebunan sawit di dunia bersamaan meningkatnya permintaan minyak nabati akibat Revolusi Industri pertengahan abad ke-19.

Dalam pengelolaan Perkebunan Sawit di indonesia ada yang dilakukan oleh rakyat dan perusahaan besar, baik pemerintah maupun swasta. Dalam manajemen pengelolaan yang masingmasing perusahaan mempunyai seni dan cara tersendiri mulai dari land clering, penanaman sampai dengan menghasilkan minyak, yang dikelola dengan wadah organisasi yang berbedabeda.
Perkebunan kelapa sawit merupakan bagian penting dari sistem pendapatan keuangan masyarakat guna kelancaran kegiatan perekonomian suatu masyarakat. Perkebunan kelapa sawit merupakan alternatif bagi masyarakat dalam memilih pekerjaan yang sesuai dengan dasar kemampuan masyarakat. Perkebunan kelapa sawit juga terbukti dapat bertahan dalam kondisi krisis ekonomi Indonesia dalam akhir dekade lalu, dan sebagai alternatif terhadap sistem kapitalis dan sistem sosialis. (Buchari, Alma, 2005:56)

Taraf hidup yang baik merupakan tujuan utama bagi petani yang dalam hal ini sangat tergantung dari pendapatan yang diperoleh, akan tetapi pada kenyataannya sebagian dari mereka relatif masih berpenghasilan rendah sehingga berpengaruh pada kehidupan sehari-hari.

Sebagian besar penduduk di Kecamatan Segah bekerja disektor pertanian khususnya pada usaha tani kelapa sawit. Besar kecilnya pendapatan usaha tani kelapa sawit yang diterima oleh penduduk di Kecamatan Segah dipengaruhi oleh biaya produksi. Jika produksi dan harga jual kelapa sawit semakin tinggi maka akan meningkatkan penerimaan. Apabila biaya produksi 
lebih tinggi dari penerimaan maka akan mempengaruhi pendapatan.

Di sisi lain, diluar perannya sebagai penyumbang devisa nonmigas dengan persentase cukup signifikan, kelapa sawit juga telah menghidupi jutaan rakyat yang bekerja di sektor ini karena sebagian besar perkebunan kelapa sawit diusahakan oleh rakyat. Ditambah lagi dengan kebutuhan kelapa sawit dunia yang setiap tahun semakin meningkat dengan ditandai semakin berkembangnya industri-industri yang menggunakan bahan baku kelapa sawit.

Di Kabupaten Berau, kehadiran perkebunan kelapa sawit telah mengeliminasi jenis perkebunan dan pertanian lainnya, lewat konversi lahan. Sekitar 5\% lahan perkebunan kelapa sawit di Kabupaten Berau telah berubah menjadi perkebunan kelapa sawit (Dinas Perkebunan dan Pertanian, 2016). Salah satu produsen kelapa sawit di Kabupaten Berau adalah Kecamatan Segah. Kecamatan Segah masuk kategori yang memiliki tingkat produksi kelapa sawit rakyat terbesar di Kabupaten Berau.

Kecamatan Segah yang berada di Kabupaten Berau adalah kecamatan yang memiliki luas lahan dan produksi kelapa sawit tertinggi di Kabupaten Berau. Namun, luas lahan +1.258 (ha) dan tingkat produksi kelapa sawit rakyat yang tinggi belum tentu menujukkan petani kelapa sawit mandiri Kecamatan Segah lebih menguntungkan.

\section{RUMUSAN MASALAH}

Berdasarkan uraian diatas, maka dalam penelitian ini penulis mengangkat judul "Pengaruh Biaya Produksi Terhadap Pendapatan Petani Mandiri Kelapa Sawit Di Kecamatan Segah".

Adapun rumusan masalah yang dikemukakan yaitu "apakah Biaya Produksi Berpengaruh Positif Terhadap Pendapatan Petani Mandiri Kelapa Sawit di Kecamatan Segah"?

\section{TUJUAN DAN KEGUNAAN}

Tujuan dari penelitian ini adalah untuk mengetahui dan menganalisis pendapatan petani mandiri kelapa sawit di Kecamatan Segah. Sedangkan kegunaan yang diharapkan penulis dari hasil penelitian ini adalah sebagai bahan masukkan bagi petani mandiri kelapa sawit di Kecamatan Segah dalam memilih komoditi yang terbaik untuk diusahakan dan sebagai informasi, referensi bagi pihak-pihak yang membutuhkan baik pihak akademis maupun nonakademis.

\section{KAJIAN PUSTAKA KAJIAN TEORI Pengertian Ekonomi Pembangunan}

Pembangunan ekonomi berarti adanya suatu proses pembangunan yang terjadi terus menerus yang bersifat menambah dan memperbaiki segala sesuatu menjadi lebih baik lagi. Adanya proses pembangunan itu diharapkan adanya kenaikan pendapatan riil masyarakat berlangsung untuk jangka panjang.

\section{Biaya Produksi}

Pengertian biaya produksi menurut Mulyadi (2007:14), "Biaya produksi adalah biaya-biaya yang terjadi untuk mengolah bahan baku menjadi barang jadi yang siap dijual". Menurut Yana Karyana (2008:81), "Biaya produksi adalah biayabiaya yang dikeluarkan dalam proses produksi atau semua beban yang ditanggung oleh produsen untuk menghasilkan suatu barang atau jasa". Dari pengertian tersebut yang dimaksud dengan biaya produksi adalah semua biaya yang disebabkan karena adanya proses produksi.

\section{Ekonomi Pertanian}

Ekonomi pertanian merupakan cabang dari ilmu ekonomi yang mempelajari tetang usaha-usaha petani dalam memenuhi kebutuhan melalui kegiatan pertanian, meliputi kegiatan menghasilkan atau memproduksi hasil pertanian dan menjual hasil pertanian itu sehingga memperoleh pendapatan.

\section{Pengertian Pendapatan}

Menurut Kamus Besar Bahasa Indonesia, pengertian pendapatan adalah hasil kerja (usaha dan sebagainya). Pengertian pendapatan menurut Kamus Besar Bahasa Indonesia merupakan definisi pendapatan secara umum. Pada perkembangannya, pengertian pendapatan memiliki penafsiran yang berbeda-beda tergantung dari latar belakang disiplin ilmu yang digunakan untuk menyusun konsep pendapatan bagi pihakpihak tertentu.

Pendapatan didefinisikan sebagai suatu penghasilan yang diterima karena adanya aktivitas, usaha, dan pekerjaan. Atau dapat juga diperoleh dari penjualanhasil produksi ke pasar. Pendapatan sangat berpengaruh bagi kelangsungan hidup seseorang maupun perusahaan, semakin besar pendapatan yang diperoleh makasemakin besar kemampuan 
seseorang atau perusahaan untuk membiayai segalapengeluaran dan kegiatan-kegiatan yang akan dilakukan. Tinggi rendahnyapendapatan seseorang tergantung pada faktor-faktor seperti umur, jenis kelamin,kemampuan,pendidikan dan pengalaman.

\section{Pengertian Petani}

Pengertian petani dapat di definisikan sebagai pekerjan pemanfaatan sumber daya hayati yang dilakukan manusia untuk menghasilkan bahan pangan, bahan baku industri, atau sumber energi, serta untuk mengelola lingkungan hidupnya guna memenuhi kebutuhan hidup dengan mengunakan peralatan yang bersifat tradisional dan modern. Secara umum pengertian dari pertanian adalah suatu kegiatan manusia yang termasuk di dalamnya yaitu bercocok tanam, peternakan, perikanan dan juga kehutanan.Petani dalam pengertian yang luas mencakup semua usaha kegiatan yang melibatkan pemanfaatan makhluk hidup (termasuk tanaman, hewan, dan mikroba) untuk kepentingan manusia. Dalam arti sempit, petani juga diartikan sebagai kegiatan pemanfaatan sebidang lahan untuk membudidayakan jenis tanaman tertentu, terutama yang bersifat semusim.

\section{Tanaman Kelapa Sawit}

Kelapa sawit merupakan tumbuhan tropis yang tergolong dalam familiPalmae dan berasal dari Afrika Barat. Meskipun demikian, dapat tumbuh di luar daerah asalnya, termasuk Indonesia. Hingga kini tanaman ini telah diusahakan dalam bentuk perkebunan dan pabrik pengolahan kelapa sawit.

Kelapa sawit merupakan tanaman dengan nilai ekonomis yang cukup tinggi karena merupakan salah satu tanaman penghasil minyak nabati. Bagi Indonesia, kelapa sawit memiliki arti penting karena mampu menciptakan kesempatan kerja bagi masyarakat dan sebagai sumber perolehan devisa negara. Sampai saat ini, Indonesia merupakan salah satu produsen utama minyak sawit dunia selain Malaysia dan Nigeria.

\section{KAJIAN EMPIRIS}

Sebagai bahan referensi dan rujukan terhadap analisis penelitian ini, maka disajikan beberapa hasil dari penelitian terdahulu diantaranya oleh Husni (2015), dengan judul penelitian "Pengaruh Luas Lahan Dan Modal Terhadap Produksi Petani
Mandiri Kelapa Sawit Di Kecamatan Segah Kabupaten Berau".Hasil penelitian menunjukkan bahwa keeratan faktor produksi luas lahan dan modal kerja terhadap produksi petani mandiri kelapa sawit adalah sebesar 0,99 , dan nilai koefisien determinasinya sebesar 0,98 atau $98 \%$ variasi naik turunnya produksi petani mandiri dipengaruhi oleh luas lahandan modal kerja sedangkan sisanya dipengaruhi faktor lain .

Rifka (2015), Analisis Pengaruh Pendapatan Daerah Dan Jumlah Penduduk Terhadap Belanja Daerah Di Kabupaten Berau". Hasil penelitian menunjukkan bahwa variabel pendapatan daerah tidak berpengaruh signifikan secara parsial terhadap belanja daerah, sedangkan jumlah penduduk berpengaruh signifikan secara parsial terhadap belanja daerah Kabupaten Berau.

Wahyudi (2016), “Analisis Pendapatan Usahatani Padi Sawah Di Desa Rokan Koto Ruang kecamatan IV Koto Kabupaten Rokan Hulu". Hasil penelitian menunjukkan bahwa bahwa total biaya yang dibutuhkan dalam usahatani padi sawah petani responden di Desa Rokan Koto Ruang adalah sebesar Rp.16.439.377,-. yang terdiri dari biaya tunai sebesar Rp.10.637.977,- dan biaya yang diperhitungkan sebesar Rp.5.801.400,-. Sedangkan penerimaan Rp.28.2182.000,-Pendapatan atas biaya tunai sebesar Rp.17.544.023,- dan pendapatan bersih (keuntungan)sebesar Rp.11.742.623,-. Return Cost Ratio (RCR) adalah 1,71, dari perhitungan penerimaan dibagi dengan total biaya. Artinya bahwa setiap Rp.1,00 biaya yang dikeluarkan maka akan mendapatkan penerimaan sebesar Rp.1,71 dan keuntungan Rp.0,71.

\section{KERANGKA PIKIR PENELITIAN}

Adapun kerangka pikir penelitian adalah sebagai berikut :

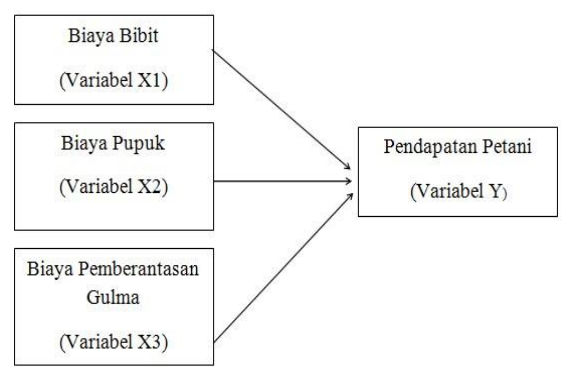

Gambar 1 Kerangka Pikir Penelitian 


\section{HIPOTESIS}

Dalam hal hipotesis

ini penulis memberikan

pada penelitian ini yaitu :

1. Dimana "Diduga, bahwa biaya bibit berpengaruh terhadap pendapatan mandiri kelapa sawit di Kecamatan Segah".

2. Dimana "Diduga, bahwa biaya pupuk berpengaruh terhadap pendapatan mandiri kelapa sawit di Kecamatan Segah".

3. Dimana "Diduga, bahwa biaya pemberantasan gulma berpengaruh terhadap pendapatan mandiri kelapa sawit di Kecamatan Segah".

\section{METODA PENELITIAN \\ Definisi Operasional}

Adapun definisi operasional dalam penelitian ini dengan judul"Analisis Pendapatan Petani Mandiri Kelapa Sawit di Kecamatan Segah" sebagai berikut:

1. Petani yang dimaksud dalam penelitian ini adalah petani kelapa sawit mandiri di Kecamatan Segah.

2. Biaya produksi adalah biaya yang digunakan dalam proses produksi yang terdiri dari bahan baku langsung, tenaga kerja langsung dan biaya overhead pabrik. Biaya bproduksi ini disebut juga biaya produk yaitu biaya- biaya yang dapat dihubungkan dengan suatu produk, dimana biaya ini merupakan bagian dari persediaan

3. Pendapatan adalah suatu penghasilan yang diterima karena adanya aktivitas, usaha, dan pekerjaan.

4. Pendapatan yang dimaksud adalah pendapatan petani mandiri kelapa sawit di Kecamatan Segah Tahun 2016. Pendapatan petani kelapa sawit $(\mathrm{Y})$ adalah selisih antara penerimaan (hasil panen dikali harga kelapa sawit per $\mathrm{kg}$ ) dengan total biaya variabel, diukur dalam satuan rupiah/ton selama setahun.

5. Adapun indikator pendukung pendapatan petani mandiri di Kecamatan Segah yaitu Biaya Bibit (Variabel X1), Biaya Pupuk (Variabel X2), Biaya Pemberantasan Gulma (Variabel X3) dan Pendapatan Petani Kelapa Sawit Mandiri (Variabel Y). Besar kecilnya pendapatan petani kelapa sawit yang diterima oleh masyarakat di Kecamatan Segah dipengaruhi oleh biaya produksi. Jika produksi dan harga jual kelapa sawit semakin tinggi maka akan meningkatkan penerimaan. Apabila biaya produksi lebih tinggi dari penerimaan maka akan mempengaruhi pendapatan.

\section{Unit Analisis, Populasi dan Sampel}

Unit analisis penelitian ini adalah Kecamatan Segah Kabupaten Berau. Lokasi penelitian ini ditentukan dengan pertimbangan yang mengembangkan perkebunan kelapa sawit di Kecamatan Segah dengan areal areal perkebunan Kelapa Sawit.

Menurut Sugiyono (2008:115) populasi adalah wilayah generalisasi terdiri atas obyek/subyek yang mempunyai kualitas dan karakteristik tertentu. ditetapkan oleh peneliti untuk dipelajari dan kemudian ditarik kesimpulan. Sedangkan menurut Arikunto (2006:130) populasi adalah keseluruhan subjek penelitian.

Menurut Sugiyono

(2008:116) sampel adalah sebagian dari jumlah dan karakteristik yang dimiliki oleh populasi tersebut. Sedangkan menurut Arikunto (2009:11) sampel adalah bagian dari populasi (sebagian atau wakil populasi yang diteliti). Responden penelitian ini ditentuan secara sengaja (purposive) yaitu sebanyak 10 orang petani mandiri kelapa sawit di Kecamatan Segah dan sudah menekuni usaha ini selama \pm 3 - 5 tahun (kebunnya sudah produksi). Waktu penelitian selama satu bulan, yaitu Oktober Tahun2017.

\section{Jenis Data dan Sumber Data}

Jenis data yang dipergunakan adalah data primer dan data sekunder. Data primer adalah data yang dikumpulkan dan diolah oleh peneliti dan langsung diperoleh dari objek yang diteliti, melalui wawancara langsung dengan petani mandiri pemilik perkebunan kelapa sawit dengan pola mandiri. Data sekunder adalah data yang diterbitkan atau digunakan oleh organisasi atau lembaga yang bukan merupakan hasil pengolahan peneliti. Data sekunder diperoleh dari Kantor Kecamatan Segah, Badan Pusat Statistik dan Dinas Perkebunan Kabupaten Berau. 


\section{Metode Pengumpulan Data}

Pengumpulan data dalam penelitian ini dilakukan dengan metode penelitian lapangan dan penelitian kepustakaan.

1. Penelitian lapangan (field work research), dilaksanakan dengan cara melakukan penelitian secara langsung di Kecamatan Segah untuk mengetahui secara nyata tentang perkebunan kelapa sawit.

2. Penelitian kepustakaan (library research), dilaksanakan dengan cara membaca buku atau literatur dan hasil penelitian yang berkaitan dengan materi penelitian.

\section{Alat Analisis}

Alat analisis yang digunakan untuk menguji hipotesis adalah metode statistik yaitu persamaan regresi linier berganda, koefisien korelasi, uji t dan uji F hitung sebagai berikut :

1. Analisis Regresi Linear Berganda

Analisis regresi berganda untuk menghitung besarnya pengaruh secara kuantitatif dari suatu perubahan kejadian (variabel $\mathrm{X}$ ) terhadap kejadian lainnya (variabel Y). dalam penelitian ini, analisis regresi berganda berperan sebagai teknik statistik yang digunakan untuk menguji ada tidaknya pengaruh biaya produksi terhadap pendapatan petani mandiri di Kecamatan Segah.

$$
\mathrm{Y}=\mathrm{a}+\mathrm{b}_{1} \mathrm{X}_{1}+\mathrm{b}_{2} \mathrm{X}_{2}+\mathrm{b}_{3} \mathrm{X}_{3}
$$

a. Uji t

Untuk menguji pengaruh dari masing-masing variabel bebas secara parsial atau untuk mengetahui variabel mana yang lebih mempengaruhi pendapatan petani digunakan uji-t.

\section{t tabel $=t(\alpha / 2 ; n-k-1)$}

Dengan kaidah pengambilan keputusan sebagai berikut :

1. Jika $\mathrm{t}$ hitung $>$ ttabel pada tingkat kepercayaan $90 \%(\alpha=0,10)$, maka terdapat pengaruhvariabel $\mathrm{X}$ terhadap variabel Y.
2. Jika t hitung $<$ ttabel pada tingkat kepercayaan $90 \%(\alpha=0,10)$, maka tidak terdapat pengaruh variabel $\mathrm{X}$ terhadap variabel Y.

b.Uji F

Untuk mengetahui positif atau tidaknya pengaruh biaya produksi terhadap pendapatan petani mandiri kelapa sawit di Kecamatan Segah, maka digunakan uji F (Fisher Test).

\section{$\mathbf{F}$ tabel $=\mathbf{F}(\mathbf{k} ; \mathbf{n}-\mathbf{k}-\mathbf{1})$}

Dengan tingkat kesalahan pada taraf 0,10 maka kriterianya adalah :

1. Jika $F_{\text {hitung }}>F_{\text {tabel }}$ Hipotesis diterima artinya variabel X1biaya bibit, variabel X2 biaya pupuk dan variabel X3 biaya pemberantasan gulma berpengaruh secara simultan terhadap variabel $\mathrm{Y}$ pendapatan petani mandiri kelapa sawit di Kecamatan Segah.

2. Jika $F_{\text {hitung }}<F_{\text {tabel Hipotesis }}$

Ditolakvariabel X1 biaya bibit, variabel X2 biaya pupuk dan variabel X3 biaya pemberantasan gulmatidak berpengaruh secara simultan terhadap variabel $\mathrm{Y}$ pendapatan petani mandiri kelapa sawit di Kecamatan Segah.

\section{HASIL PENELITIAN GAMBARAN UMUM KECAMATAN SEGAH \\ Letak dan Geografis}

Kecamatan Segah merupakan salah satu dari tiga belas kecamatan yang berada di wilayah Kabupaten Berau dengan batasbatas daerah yaitu sebagai berikut :

a. Sebelah utara berbatasan dengan Kecamatan Gunung Tabur

b. Sebelah timur berbatasan dengan Kecamatan Teluk Bayur

c. Sebelah selatan berbatasan dengan Kecamatan Kelay Luas wilayah Kecamatan Segah adalah $5.1666,40 \quad \mathrm{Km}^{2}$ dimana sekitar 5.153,40 $\mathrm{Km}^{2}$ merupakan daerah daratan sedangkan sisanya $13,00 \mathrm{Km}^{2} \quad$ berupa wilayah perairan. Wilayah administrasi 
Kecamatan Segah saat ini terdiri 13 kampung definif dan 92 rukun tetangga. Jarak antara Kecamatan Segah dengan Kota Tanjung Redeb yang merupakan ibukota Kabupaten Berau $\pm 92 \mathrm{Km}^{2}$. Bentuk topografi Kecamatan Segah cukup bervariasi, dengan berbagai bentuk lembah dan perbukitan dengan berbagai ketinggian dan kemiringan. Benteng alam yang menghiasi bentuk permukaan Kecamatan ini juga sangat beraneka ragam. Dataran wilayah Kecamatan Segah terdiri dari beberapa gugusan bukit. Selain bentuk daratan yang khas, di wilayah ini juga terdapat beberapa sungai besar dan kecil serta danau dengan ukuran yang sangat bervariasi. Sungai besar seperti Sungai Segah melintasi hamper sebagian wilayah Kecamatan Segah.

\section{Penduduk}

Jumlah penduduk di Kecamatan Segah yangdirincikan per kampung pada tahun

2014 dapat dilihat pada tabel 2 dibawah ini :

Tabel 2. Jumlah Penduduk Kecamatan Segah

\begin{tabular}{|c|c|c|c|c|}
\hline No & $\begin{array}{c}\text { Kode } \\
\text { Kampung }\end{array}$ & Nama Kampung & $\begin{array}{c}\text { Jumlah } \\
\text { KK }\end{array}$ & $\begin{array}{c}\text { Jumlah } \\
\text { Penduduk }\end{array}$ \\
\hline 1. & 04.001 & Long Laai & 153 & 551 \\
\hline 2. & 04.002 & Punan Segah & 23 & 79 \\
\hline 3. & 04.003 & Long Ayap & 34 & 135 \\
\hline 4. & 04.004 & Long Ayan & 123 & 508 \\
\hline 5. & 04.005 & Punan Malinau & 267 & 970 \\
\hline 6. & 04.006 & Punan Mahakam & 70 & 265 \\
\hline 7. & 04.007 & Gunung Sari & 1.027 & 5.212 \\
\hline 8. & 04.008 & Pandan Sari & 295 & 1.245 \\
\hline 9. & 04.009 & Bukit Makmur & 262 & 866 \\
\hline 10. & 04.010 & Harapan Jaya & 418 & 1.491 \\
\hline 11. & 04.011 & Tepian Buah & 204 & 787 \\
\hline 12. & 04.012 & Siduung Indah & 123 & 502 \\
\hline 13. & 04.012 & Batu Rajang & 67 & 234 \\
\hline \multicolumn{3}{|c|}{ Jumlah } & 3.066 & 12.845 \\
\hline
\end{tabular}

\section{DATA HASIL PENELITIAN}

Karakteristik Responden Responden dalam penelitian ini adalah 10 orang petani mandiri kelapa sawit di Kecamatan Segah dan sudah menekuni usaha ini selama \pm 3 - 5 tahun (kebunnya sudah produksi).

\section{Harga Jual Kelapa Sawit}

Hasil produksi kelapa sawit petani mandiri di Kecamatan Segah dalam satu tahun biasanya hasilnya dipasarkan langsung

kepada perusahaan inti kelapa sawit melalui koperasi yang langsung datang kepada para petani.Untuk lebih jelasnya harga jual kelapa sawit dari hasil produksi petani mandiri di Kecamatan Segah yang dijadikan sampel dapat di lihat dari table 6

berikut:

Tabel 6. Harga Jual Kelapa Sawit dari Koperasi 2017

\begin{tabular}{|c|c|c|c|}
\hline No & Umur & Lokasi & Harga Jual \\
\hline Responden & Kelapa Sawit & Kampung & $(\mathrm{Rp} / \mathrm{Kg})$ \\
\hline 1 & \pm 3 Tahun & Gunung Sari & 1.521 \\
\hline 2 & \pm 5 Tahun & Gunung Sari & 1.632 \\
\hline 3 & \pm 4 Tahun & Harapan Jaya & 1.622 \\
\hline 4 & \pm 4 Tahun & Harapan Jaya & 1.622 \\
\hline 5 & \pm 5 Tahun & Tepian Buah & 1.632 \\
\hline 6 & \pm 5 Tahun & Tepian Buah & 1.632 \\
\hline 7 & \pm 5 Tahun & Punan Malinau & 1.632 \\
\hline 8 & \pm 5 Tahun & Punan Malinau & 1.632 \\
\hline 9 & \pm 5 Tahun & Pandan Sari & 1.632 \\
\hline 10 & \pm 4 Tahun & Long Ayan & 1.622 \\
\hline
\end{tabular}

Tabel 7. Produksi Kelapa Sawit Responden 2017

\begin{tabular}{|c|c|c|c|c|}
\hline \multirow{2}{*}{$\begin{array}{c}\text { No } \\
\text { Responden }\end{array}$} & \multirow[t]{2}{*}{ Nama } & \multirow[t]{2}{*}{ Kampung } & \multirow{2}{*}{$\begin{array}{l}\text { Luas } \\
\text { Lahan } \\
\text { (Ha) }\end{array}$} & \multirow{2}{*}{$\begin{array}{l}\text { Produksi } \\
(\mathrm{kg})\end{array}$} \\
\hline & & & & \\
\hline 1 & Pahenneng & Gunung Sari & \pm 1 & 4.931 \\
\hline 2 & Isak Tangkin & Gunung Sari & \pm 3 & 12.868 \\
\hline 3 & Sutikno & Harapan Jaya & $\pm 1,5$ & 4.007 \\
\hline 4 & Waluyo & Harapan Jaya & \pm 2 & 3.637 \\
\hline 5 & Lawai Iban & Tepian Buah & $\pm 2,5$ & 3.186 \\
\hline 6 & Sandra Siregar & Tepian Buah & \pm 3 & 16.667 \\
\hline 7 & Sulaiman Sakai & Punan Malinau & \pm 4 & 15.319 \\
\hline 8 & Kila Ncuk & Punan Malinau & \pm 4 & 15.625 \\
\hline 9 & Asa Nyuk & Pandan Sari & \pm 4 & 13.174 \\
\hline 10 & Agus Daniel & Long Ayan & \pm 3 & 8.323 \\
\hline & & Jumlah & & 97.737 \\
\hline
\end{tabular}

\section{BIAYA PRODUKSI}

\section{Biaya Bibit}

Tabel 8. Jumlah Biaya Bibit Yang Dikeluarkan Petani Kelapa Sawit

\begin{tabular}{|c|l|r|r|}
\hline No & \multicolumn{1}{|c|}{ Nama } & \multicolumn{1}{c|}{ Lokasi } & \multicolumn{1}{c|}{ Nilai Bibit } \\
Responden & Responden & Kampung & \multicolumn{1}{c|}{$(\mathrm{Rp})$} \\
\hline 1 & Pahenneng & Gunung Sari & 1.300 .000 \\
\hline 2 & Isak Tangkin & Gunung Sari & 3.150 .000 \\
\hline 3 & Sutikno & Harapan Jaya & 1.300 .000 \\
\hline 4 & Waluyo & Harapan Jaya & 900.000 \\
\hline 5 & Lawai Iban & Tepian Buah & 900.000 \\
\hline 6 & Sandra Siregar & Tepian Buah & 4.300 .000 \\
\hline 7 & Sulaiman Sakai & Punan Malinau & 4.950 .000 \\
\hline 8 & Kila Ncuk & Punan Malinau & 3.600 .000 \\
\hline 9 & Asa Nyuk & Pandan Sari & 3.150 .000 \\
\hline 10 & Agus Daniel & Long Ayan & 2.250 .000 \\
\hline & & Jumlah & $25.800 .000,00$ \\
\hline
\end{tabular}




\section{Biaya Pupuk}

Tabel 9, Nilai Pupuk Yang Digunakan Selama Produksi

\begin{tabular}{|c|l|l|r|}
\hline $\begin{array}{c}\text { No } \\
\text { Responden }\end{array}$ & \multicolumn{1}{|c|}{ Nama } & \multicolumn{1}{|c|}{ Kampung } & Nilai Pupuk (Rp) \\
\hline 1 & Pahenneng & Gunung Sari & 1.500 .000 \\
\hline 2 & Isak Tangkin & Gunung Sari & 5.200 .000 \\
\hline 3 & Sutikno & Harapan Jaya & 1.500 .000 \\
\hline 4 & Waluyo & Harapan Jaya & 1.350 .000 \\
\hline 5 & Lawai Iban & Tepian Buah & 1.500 .000 \\
\hline 6 & Sandra Siregar & Tepian Buah & 7.000 .000 \\
\hline 7 & Sulaiman Sakai & Punan Malinau & 5.750 .000 \\
\hline 8 & Kila Ncuk & Punan Malinau & 5.250 .000 \\
\hline 9 & Asa Nyuk & Pandan Sari & 4.500 .000 \\
\hline 10 & Agus Daniel & Long Ayan & 3.000 .000 \\
\hline \multicolumn{3}{|c|}{ Jumlah } \\
\hline Sumber : Hasil Penelitian Tahun 2017 \\
\hline \multicolumn{3}{|c|}{} \\
\hline
\end{tabular}

\section{Biaya Pemberantasan Gulma dan Pemangkasan}

Tabel 10. Biaya Pemberantasan Gulma dan Pemangkasan.

\begin{tabular}{|c|l|l|r|}
\hline $\begin{array}{c}\text { No } \\
\text { Responden }\end{array}$ & \multicolumn{1}{|c|}{ Nama } & \multicolumn{1}{|c|}{ Lokasi } & $\begin{array}{c}\text { Biaya Pemberantasan } \\
\text { Gulma (Rp) }\end{array}$ \\
\hline 1 & Pahenneng & Gunung Sari & 1.300 .000 \\
\hline 2 & Isak Tangkin & Gunung Sari & 2.500 .000 \\
\hline 3 & Sutikno & Harapan Jaya & 1.200 .000 \\
\hline 4 & Waluyo & Harapan Jaya & 1.000 .000 \\
\hline 5 & Lawai Iban & Tepian Buah & 1.000 .000 \\
\hline 6 & Sandra Siregar & Tepian Buah & 3.750 .000 \\
\hline 7 & Sulaiman Sakai & Punan Malinau & 3.300 .000 \\
\hline 8 & Kila Ncuk & Punan Malinau & 3.250 .000 \\
\hline 9 & Asa Nyuk & Pandan Sari & 3.250 .000 \\
\hline 10 & Agus Daniel & Long Ayan & 2.100 .000 \\
\hline \multicolumn{3}{|c|}{ Jumlah } \\
\hline
\end{tabular}

\section{Pendapatan}

Tabel 11. Pendapatan Petani Kelapa Sawit Kecamatan Segah

\begin{tabular}{|c|c|c|r|}
\hline $\begin{array}{c}\text { No } \\
\text { Responden }\end{array}$ & $\begin{array}{c}\text { Nama } \\
\text { Responden }\end{array}$ & $\begin{array}{c}\text { Lokasi } \\
\text { Kampung }\end{array}$ & $\begin{array}{c}\text { Pendapatan } \\
\text { Petani } \\
\text { (Rp) }\end{array}$ \\
& Pahenneng & Gunung Sari & 7.500 .000 \\
2 & Isak Tangkin & Gunung Sari & 21.000 .000 \\
& Sutikno & Harapan Jaya & 6.500 .000 \\
\hline 4 & Waluyo & Harapan Jaya & 5.900 .000 \\
\hline 5 & Lawai Iban & Tepian Buah & 5.200 .000 \\
\hline 6 & Sandra Siregar & Tepian Buah & 27.200 .000 \\
\hline 7 & Sulaiman Sakai & Punan Malinau & 25.000 .000 \\
& Kila Ncuk & Punan Malinau & 25.500 .000 \\
\hline 9 & Asa Nyuk & Pandan Sari & 21.500 .000 \\
\cline { 3 - 3 } 10 & Agus Daniel & Long Ayan & 13.500 .000 \\
\hline \multicolumn{3}{|c|}{ Jumlah } & 158.800 .000 \\
\hline
\end{tabular}

\section{PEMBAHASAN}

Berdasarkan

analisis

dengan perhitungan sebagaimana yang telah diuraikan di atas maka dapat diketahui bahwa persamaan regresi linier berganda pengaruh biaya bibit, biaya pupuk dan biaya pemberantasan gulma terhadap pendapatan petani mandiri kelapa sawit di Kecamatan Segah adalah :

$$
\mathrm{Y}=-1.469+0,639 \mathrm{X}_{1}+1,724 \mathrm{X}_{2}+4,150 \mathrm{X}_{3}
$$

Hasi uji korelasi menunjukkan koefisien korelasi ganda $(\mathrm{R})=0,892$ yang berarti bahwa variabel biaya bibit, biaya pupuk dan biaya pemberantasan gulma berpengaruh terhadap pendapatan petani mandiri kelapa sawit di Kecamatan Segah dan koefisien determinasi $\mathrm{R}^{\wedge} 2$ $=0,795$ yang menunjukkan bahwa pendapatan petani mandiri kelapa sawit di Kecamatan Segah dipengaruhi oleh biaya bibit, biaya pupuk dan biaya pemberantasan gulma.

Selanjutnya Uji t dengan uji parsial, yaitu untuk menguji bagaimana pengaruh masingmasing variabel bebasnya terhadap variabel terikatnya. Uji ini dapat dilakukan dengan mambandingkan $t$ hitung dengan $t$ tabel atau dengan melihat kolom signifikansi pada masingmasing t hitung .Diketahui nilai sig. X1 biaya bibit terhadap variabel $\mathrm{Y}$ pendapatan petani sebesar 0,402 >0,05 dan nilai $\mathrm{t}$ hitung $0,893<\mathrm{t}$ tabel 2,365 sehingga dapat disimpulkan bahwa variabel $\mathrm{X} 1$ biaya bibit tidak terdapat pengaruh signifikan terhadap Variabel Y pendapatan petani mandiri kelapa sawit di Kecamatan Segah.

Diketahui nilai sig. variabel X2 biaya produksi terhadap variabel $\mathrm{Y}$ pendapatan petani sebesar $0,002<0,05$ dan nilai t hitung 4,968 > 2,365 sehingga dapat disimpulkan bahwa variabel $\mathrm{X} 2$ biaya pupuk terdapat pengaruh terhadap variabel Y pendapatan petani mandiri kelapa sawit di Kecamatan Segah.

Diketahui nilai sig. variabel $\mathrm{X} 3$ biaya pemberantasan gulma terhadap variabel $\mathrm{Y}$ pendapatan petani sebesar $0,002<0,05$ dan nilai $t$ hitung 3,285>2,365 sehingga dapat disimpulkan bahwa variabel X3 biaya pemberantasan gulma terdapat pengaruh terhadap variabel $\mathrm{Y}$ pendapatan petani mandiri kelapa sawit di Kecamatan Segah.

Diketahui nilai signifikasi untuk pengaruh variabel X1 biaya bibit, X2 biaya pupuk dan X3 
biaya pemberantasan gulma terhadap variabel $\mathrm{Y}$ pendapatan petani sebesar $0,004<0,05$ dan nilai $\mathrm{F}$ hitung 13,568 > F tabel 4,26 sehingga dapat disimpulkan bahwa hipotesis yang diajukan penulis diterima yang berarti terdapat pengaruh variabel X1, variabel X2 dan variabel X3 secara simultan terhadap variabel $\mathrm{Y}$.

\section{PENUTUP}

\section{- Kesimpulan}

Berdasarkan hasil penelitian

yangtelah diuraikan pada bab sebelumnya

dan dilakukan analisis kemudian diambil

kesimpulan sebagai berikut :

1. Hipotesis yang telah penulis ajukan bahwa diduga biaya bibit, biaya pupuk dan biaya pemberantasan gulma berpengaruh positif terhadap pendapatan petani mandiri kelapa sawit, karena berdasarkan pengujian hipotesis dengan menggunakan uji $\mathrm{F}$ dimana $\mathrm{F}$ Hitung adalah 13,568> F tabel 4,26 sehingga dapat disimpulkan bahwa hipotesis yang diajukan diterima.

2. Keeratan antara biaya bibit, biaya pupuk dan biaya pemberantasan gulma terhadap pendapatan petani mandiri kelapa sawit adalah sebesar 0,892 dan nilai koefisien

\section{DAFTAR PUSTAKA}

Arikunto, Suharsimi. 2006. Prosedur PenelitianSuatu Pendekatan Praktik. Rineka Cipta. Jakarta

Arsyad, Lincolin. 2010.Ekonomi

Pembangunan. Sekolah Tinggi Ekonomi. Yogyakarta

Basran, Husni. 2015. Pengaruh Luas Lahan Dan Modal Terhadap Produksi Petani Mandiri Kelapa Sawit Di Kecamatan Segah Kabupaten Berau

Choirullah. 2007. Ekonomi Pembanguan. http://epserv.fe.unila.ac .id.

Ghozali, Imam. 2005. Aplikasi Analisis Multivariate program SPSS, Badan Penerbit Universitas Diponegoro.Semarang

Halim, Abdul (2010). Akuntansi Daerah Sektor Publik. Salemba 4. Jakarta

J, Supranto. 2005. Ekonometrika. Ghalia Indonesia. Bogor

Milfitra, Wahyudi. 2016. Analisis Pendapatan Usahatani Padi Sawah Di Desa Rokan Koto Ruang kecamatan IV Koto Kabupaten Rokan Hulu. determinasinya sebesar 0,795 yang menunjukkan bahwa pendapatan petani mandiri kelapa sawit di Kecamatan Segah dipengaruhi oleh harga jual dan biaya produksi. Sedangkan sisanya sebesar $2,05 \%$ (1 - 0,795) adalah faktor-faktor yang tidak diteliti.

- Saran

Dari kesimpulan yang telah

dikemukakan, dapat disajikan beberapa saran-saran yaitu sebagai berikut :

1. Mengingat besarnya potensi pertanian kelapa sawit di Kecamatan Segah yang cukup besar maka sebaiknya pemerintah Kabupaten Berau dapat membantu pengembangan usaha ini dengan lebih memperhatikan kondisi petani baik dari sisi harga jual, biaya produksi maupun sistem pemasarannya.

2. Dinas Pertanian dan Perkebunan diharapkan memberikan informasi yang relevan dalam kaitannya dengan pembahasan yang diajukan demi kemajuan dan keberhasilan petani mandiri di Kecamatan Segah.

Mulyadi. 2009. Sistem Perencanaan dan Pengendalian manajmen sistem pelipat gandaan perusahaan. Salemba 4. Jakarta

Rangkuti, Freddy. 2006. Riset Pemasaran. Gramedia Pustaka Utama. Jakarta

Sugiyono. 2009. Metodologi Penelitian. Alafbeta. Bandung

Todaro P. Michael. 2008. Pembangunan

Ekonomi Dunia Ketiga, Edisi Ketujuh, Erlangga. Jakarta

Ungau, Rifka. 2015. Analisis Pengaruh Pendapatan Daerah Dan Jumlah Penduduk Terhadap Belanja Daerah Di Kabupaten Berau.

Usman, Husaini dan Setiady, Purnomo. 2006. Metodologi Penelitian Sosial. Bumi Aksara. Jakarta

Winardy. 2005. Pengantar Ilmu Ekonomi. Tarsito. 